\title{
ПРИНЦИПИ ОРГАНІЗАЦІЇ ПРОБЛЕМНО-ОРІЄНТОВАНОГО НАВЧАННЯ НА КАФЕДРІ ГІСТОЛОГІЇ, ЦИТОЛОГІЇ ТА ЕМБРІОЛОГІЇ В УМОВАХ ВПРОВАДЖЕННЯ СУЧАСНИХ ІНФОРМАЦІЙНИХ ТЕХНОЛОГІЙ
}

\author{
Запорізький державний медичний університет мОЗ України
}

\begin{abstract}
У статті шляхом анкетування старших наукових співробітників і студентів кафедри гістології, цитології та ембріології визначені основні підходи до формування принципів проблемно-орієнтованого навчання студентів і його об'єктивного контролю в умовах впровадження сучасних інформаційних технологій. Впровадження на кафедрі гістології, цитології та ембріології тестового контролю для контролю знань і ситуаційних завдань для оцінки розвитку клінічного мислення дозволяє дати об'єктивну оцінку того, наскільки студенти розуміють зв'язок між теоретичним матеріалом і практичними діями, вміють аналізувати, узагальнювати матеріал і прогнозувати розвиток ситуацій.

До безперечних переваг рейтингового контролю віднесено: оцінку результатів окремих ланок роботи, що забезпечує надійність контролю (тестовий контроль і ситуаційні задачі, діагностика 2 мікропрепаратів і електронограми) та задовольняє вимоги змістової і конструктивної валідності (відповідність форм і мети); розгорнутий поточний контроль (об'єднує і реалізує мотиваційну і виховну функції); деталізовану та поетапну процедуру контролю.
\end{abstract}

Ключові слова: проблемно-орієнтоване навчання, педагогічний контроль, компетенції, комп'ютерні технології.

\section{ПРИНЦИПЫ ОРГАНИЗАЦИИ ПРОБЛЕМНО-ОРИЕНТИРОВАННОГО ОБУЧЕНИЯ НА КАФЕДРЕ ГИСТОЛОГИИ, ЦИТОЛОГИИ И ЭМБРИОЛОГИИ В УСЛОВИЯХ ВНЕДРЕНИЯ СОВРЕМЕННЫХ ИНФОРМАЦИОННЫХ ТЕХНОЛОГИЙ}

\author{
Запорожский государственный медицинский университет мОз Украины
}

\begin{abstract}
В статье путем анкетирования старших научных сотрудников и студентов кафедры гистологии, цитологии и эмбриологии определены основные подходы к формированию принципов проблемно-ориентированного обучения студентов и его объективного контроля в условиях внедрения современных информационных технологий. Внедрение на кафедре гистологии, цитологии и эмбриологии тестового контроля для контроля знаний и ситуационных задач для оценки развития клинического мышления позволяет дать объективную оценку того, насколько студенты понимают связь между теоретическим материалом и практическими действиями, умеют анализировать, обобщать материал и прогнозировать развитие ситуаций. К инновациям образовательной диагностики можно отнести успешное использование на кафедре гистологии, цитологии и эмбриологии принципов модульного построения обучения и рейтингового контроля с использованием компьютерных программ. Несомненные преимущества рейтингового контроля состоят в следующем: оценка результатов отдельных звеньев работы обеспечивает надежность контроля (тестовый контроль и ситуационные задачи, диагностика 2 микропрепаратов и электронограммы); такая его форма удовлетворяет требования содержательной и конструктивной валидности (соответствие форм и целей); развернутый текущий контроль объединяет и реализует мотивационную и воспитательную функции; детализированная и поэтапная процедура контроля развивает у студентов навыки самооценки работы, формирует опыт самоконтроля в профессиональной деятельности.
\end{abstract}

Ключевые слова: проблемно-ориентированное обучение, педагогический контроль, компетенции, компьютерные технологии.

\section{ORGANIZATION PRINCIPLES OF PROBLEM-BASED LEARNING AT THE DEPARTMENT OF HISTOLOGY, CYTOLOGY AND EMBRYOLOGY IN THE CONDITIONS OF MODERN INFORMATION TECHNOLOGIES}

S. S. Klyuchko

\section{Zaporizhian State Medical University}

The article by questioning senior researchers and students of the Department of Histology, Cytology and Embryology Authority identified the main approaches to the formation of the principles of problem-based learning students and objective

(C) С. С. Ключко 


\section{МЕДИЧНА ІНФОРМАТИКА TA IHЖЕНЕРІЯ}

control in the conditions of modern information technologies. Implementation at the Department of Histology, Cytology and Embryology test control for control of knowledge and case studies for the evaluation of clinical thinking allows us to give an objective assessment of how students understand the connection between the theoretical material and practical actions, are able to analyze, synthesize the material and to predict development of the situation. To innovate the educational diagnosis can be attributed to the successful use of the Department of Histology, Cytology and Embryology principles of modularity and rating control training using computer programs. The undoubted advantages of the rating control are: evaluation of the individual units of work ensures the reliability of the control (test control and situational problems, diagnostics 2 micropreparations and electron diffraction); so its form satisfies the requirements of content and construct validity (compliance with the forms and purposes); Extended Monitoring integrates and implements motivational and educational functions; detailed and phased control procedure to develop students' skills of self-work, forms the experience of self-control in professional activities.

Key words: problem-based learning, pedagogical supervision, competence, computer technologies.

Вступ. Перехід до особистісно- та проблемноорієнтованого навчання на кафедрі гістології, цитології та ембріології настійно вимагає від викладачів колективу кафедри розроблення системи педагогічного контролю, що буде відкритою та зрозумілою студентам, зможе обговорюватися в спеціальних групах, піддаватися експертній оцінці та коригуванню після проведення заліків та іспитів [1-3]. Результати оцінки знань і дій студентів повинні стати об'єктом їхніх власних інтересів, служити для них постійним і надійним показником успішності просування до обраної професії [4, 5].

Метою даної роботи $є$ аналіз педагогічних i психологічних аспектів навчання в умовах впровадження сучасних інформаційних технологій.

Матеріали та методи дослідження. Шляхом анкетування старших наукових співробітників та студентів кафедри гістології, цитології та ембріології визначені основні підходи до формування принципів проблемно-орієнтованого навчання студентів і його об'єктивного контролю.

Результати та обговорення. Базою реалізації достовірної системи контролю є всебічне використання комп'ютерів, технічних та аудіовізуальних систем, сучасні форми їі здійснення, що відображають умови професійної діяльності лікаря, а саме - імітаційні ділові ігри, що також із успіхом можуть впроваджуватися на базі комп'ютерної техніки.

Викладач у ході контрольно-оцінювальних процедур, як експерт і наставник, виділяє показники навчальної та майбутньої лікарської діяльності студента: рівень сформованості основ професійної діяльності, ступінь мотивації до конкретного предмета, дисципліни і професії в цілому, рівень інтелектуального, психологічного, морального розвитку студентів з урахуванням їх індивідуальних особливостей i характеру міжособистісних стосунків. Завдання і питання для контролю вихідних знань служать для самопідготовки та самоконтролю студентів. Їх зміст для занять залежить від завдання, яке ставиться перед студентами при самопідготовці, від складності теми та поставленої на занятті мети.

До початку заняття доцільно провести контроль знання загальнотеоретичних питань, основних визначень і класифікацій. При підборі змісту завдань для контролю вихідних знань слід враховувати матеріали схем логіко-дидактичної структури, особливо ті питання, які там лише позначені, але докладно не викладені.

Форма завдань повинна задовольняти таким умовам: бути чіткою, передбачати однозначні відповіді, стислі розв'язання. Впровадження на кафедрі гістології, цитології та ембріології тестового контролю знань і ситуаційних завдань для оцінки розвитку клінічного мислення дозволяє об'єктивно оцінити, наскільки студенти розуміють зв'язок між теоретичним матеріалом і практичними діями, вміють аналізувати, узагальнювати матеріал i прогнозувати розвиток ситуацій. Впровадження тестового контролю і ситуаційних завдань, які також можна назвати «педагогічно орієнтованими» тестами, дозволяє проаналізувати такий досвід 3 позиції як студента, так і викладача.

Однак цього недостатньо, щоб оцінити знання студента, оскільки відповідь може виявитися випадковою (обраною навмання). Для підвищення достовірності такого контролю рекомендується в одному завданні використовувати декілька тестів. Більш компактними $\epsilon$ схематизовані завданнятаблиці, в яких студент повинен одночасно вказати взаємозалежність ряду явищ, виділити супідрядні i причинно-наслідкові зв'язки. Ці завдання будуються за такою схемою: пропонується питання i дається таблиця 3 відповідями, серед яких студент зазначає знаками «плюс» вірні і «мінус» - невірні. Для перевірки точності розуміння студентом деяких положень, основних понять медичної науки найчастіше використовуються питання, сформульовані в термінах дій («Вкажіть на мікропрепа- 
раті шари сітківки», «Дайте визначення поняття «мікроциркуляторне русло» і назвіть його відділи» тощо), для контролю вихідних знань вводиться методичний та дидактичний матеріали - мікропрепарати, електронограми, малюнки, схеми, таблиці, слайди. Для уточнення і перевірки вихідних знань і одночасної самопідготовки студентів використовуються ситуаційні задачі з бази «КРОК» і завдання 3 вже пройдених тем.

Студентам важливо пояснити об'єктивні орієнтири оцінювання результатів їх навчальної діяльності. Традиційно такими орієнтирами є: конкретні предметні знання, сенс і зміст основних понять 3 дисципліни; пізнавальні та практичні навики (діагностика мікропрепарату, елетронограми); здатність діяти самостійно у навчальних та реальних ситуаціях; проектна продукція, в якій проявляється здатність не тільки до нормативної, а й до творчої діяльності, у тому числі і в нестандартних ситуаціях. До недавнього часу в число таких орієнтирів не входили навички професійного спілкування та деонтологічної поведінки. Освітня діагностика спрямована на виявлення та оцінку двох сторін навчальної діяльності - зовнішньої (матеріалізованої освітньої продукції студентів) i внутрішньої (особистісної - самопізнання і самовиховання).

Якщо в традиційному, інформаційному підході основна увага приділялася зовнішнім освітнім продуктам, то при проблемно-орієнтованому підході не менш важливими $є$ особистісне становлення людини, фахівця в процесі навчальної діяльності, розвиток його професійно значущих якостей, набуття навичок чуйної і проникливої взаємодії 3 оточуючими. Для майбутнього лікаря велику роль відіграють такі особистісні якості, як цілеспрямованість, рефлексія, здатність генерувати гіпотези, ідеї, виявляти причинно-наслідкові зв'язки, смислове та системне бачення процесів і явищ, ініціативність, адекватна самооцінка. Ця сфера поки залишається за межами звичайної контрольної процедури і розглядається лише в наукових дослідженнях, присвячених виявленню успішності навчальної та професійної діяльності.

До інновацій освітньої діагностики можна віднести успішне використання на кафедрі гістології, цитології та ембріології принципів модульного побудови навчання і рейтингового контролю. Модуль - це логічно завершена частина навчального матеріалу, обов'язково супроводжується контролем знань і умінь студентів. Основою для формування змісту модуля служать робочі програми 3 відповідної дисципліни. Число модулів залежить як від особливостей предмета, так і від бажаної частоти педагогічного контролю. Така форма навчання пов'язана 3 рейтинговою системою контролю: чим крупніший або важливіший модуль за своїм змістом, тим більше число балів йому відводиться. Як правило, в нього входять як професійні предметні знання, так і практичні вміння і навички, набуті на основі цих знань. Особливої важливості набуває співвідношення теоретичної та практичної наповненостей модуля, що визначається викладачами. Контроль при модульній побудові навчання проводиться двічі у семестр, зазвичай у нього входить залік або іспит за курсом.

Кожен модуль передбачає досягнення заздалегідь запланованого результату навчання. Підсумки контролю в рівній мірі характеризують і успішність навчальної діяльності студентів і переваги (або недоліки) педагогічної технології, обраної викладачем.

Контрольні завдання для модулів, побудованих на змістовій основі, дозволяють оцінити рівень освоєння конкретних предметних знань за видом їх використання і виявляють три рівні знань - критичний, достатній, оптимальний. Завдання для модулів, побудованих на діяльнісній основі, передбачають оцінку рівня сформованості умінь, необхідних для виконання конкретної діяльності і окремих вхідних у неї дій та операцій. У цьому випадку критичний рівень відповідає вмінню студента виконувати окремі операції і діяльність в цілому тільки за заданим алгоритмом (відтворення за зразком). Достатній рівень - самостійного виконання всіх необхідних дій при відсутності готового алгоритму (самостійна побудова всієї діяльності).

Відповідними оптимальному рівню можуть бути визнані повністю усвідомлені самостійні дії, супроводжувані вичерпними звітом і обгрунтуванням. Контрольні завдання для модулів, що поєднують знання та вміння, об'єднують спрямованість змісту модулів першого і другого типів. При рейтинговому контролі самостійної роботи студентів оцінюються окремо результат виконання завдань кожного виду занять і результати окремих етапів роботи. Оцінка (бали) за кожен окремий модуль залежить від якості та термінів виконання всіх назв завдань. Загальна оцінка діяльності студента визначається сумою балів, отриманих 3 окремих модулів і видів завдань. 


\section{МЕДИЧНА ІНФОРМАТИКА \\ TA IHЖЕНЕРIЯ}

Безперечні переваги рейтингового контролю полягають у наступному: оцінка результатів окремих ланок роботи забезпечує надійність контролю (тестовий контроль і ситуаційні задачі, діагностика 2 мікропрепаратів і електронограми); така його форма задовольняє вимоги змістової і конструктивної валідності (відповідність форм і цілей); розгорнутий поточний контроль об'єднує і реалізує мотиваційну і виховну функції; деталізована і поетапна процедура контролю розвиває у студентів навички самооцінки роботи, формує досвід самоконтролю у професійній діяльності.

Висновки. Впровадження інформаційних технологій сприяє оптимізації навчального процесу та вдосконаленню нового принципу

\section{Література}

1. Кудрявая Н. В. Педагогика в медицине / Н. В. Кудрявая. - М. : Академия, 2006. - 304 с.

2. Максимов Н. И. Разработка компетентностноориентированных основных образовательных программ: нормативно-методическая документация вуза / Н. И. Максимов. - М. : МГтУ им. А. М. Косыгина, 2011. - 188 c.

3. Грубінко В. В. Індивідуальна та самостійна робота студентів в умовах кредитно-модульної системи організації навчального процесу // Матеріали науковопрактичного семінару «Кредитно-модульна система проблемно-орієнтованого навчання студентів, його контролю. На відміну від традиційних методів навчання, використання проблемноорієнтованого принципу формує у студентів важливі компетенції - знання, навички, вміння, прагнення до саморозвитку, при цьому викладач одночасно зі студентами розвивається і вдосконалюється у професійній сфері.

Перспективи подальших досліджень. Надалі планується розробка нових форм навчання $\mathrm{i}$ контролю знань студентів за допомогою комп'ютерних технологій (діагностика мікропрепаратів в електронному вигляді, створення навчальних відеофільмів, розробка оцінювальних комп'ютерних програм).

організації навчального процесу». - Тернопіль : ТДМУ, 2004. - С. 3.

4. Журавський В. С. Болонський процес: головні принципи входження в Європейський простір вищої освіти / В. С. Журавський, М. З. Згуровський. - К. : Політехніка, 2003. - 200 c.

5. Мынбаева А. К. Инновационные методы обучения, или как интересно преподавать : учебное пособие. - 4-е изд., доп. / А. К. Мынбаева, 3. М. Садвокасова. Алматы, 2010. - 344 с. 